\title{
Control and analytical aspects of the management of financial results of enterprises
}

\author{
Guzaliya Klychova $^{1}$, Evgenia Zaugarova ${ }^{2}$, Alsou Zakirova ${ }^{1, *}$, Angelina Dyatlova $^{3}$, and Ildus \\ Gimadiev $^{1}$ \\ ${ }^{1}$ Kazan State Agrarian University, Karl Marx, 65, 420015 Kazan, Russia \\ ${ }^{2}$ Saint-Petersburg State Economic University, Sadovaya, 21, 191023, St. Petersburg, Russia \\ ${ }^{3}$ Moscow University Ministry of Internal Affairs of Russian named after V. J. Kikot, Academic \\ Volgin, 12, 117997, Moscow, Russia
}

\begin{abstract}
The presence or absence of effective internal control system at the enterprise has a significant impact on the success of business development, competitiveness increase, development of information system, improvement of quality of accounting and analytical support of enterprise management system. With the help of internal control system the directions of improvement of financial and economic activity of the enterprise are defined, the procedures allowing to maximize profit are defined, rational distribution of expenses is provided. The purpose of research - development of theoretical bases and development of recommendations about perfection of methodical maintenance of the internal control of financial results. For development of theoretical bases of internal control the article suggests conceptual model of internal control system of financial results. During the research the procedures which are carried out at internal control of financial results are ranked depending on the control stages. Working documents which promote increase of efficiency of planning of inspection, timely collection of proof and full realization of control measures are offered. The application of the developed working documents in practical activities, will contribute to achieving the goals and solving urgent problems of internal control for effective management of the financial results of the production activities of the enterprise.
\end{abstract}

\section{Introduction}

An important part of the management of financial and economic activities of an economic entity is information about its financial condition, which is characterized by financial results - profit or loss $[1,2]$. Profit is a key concept of market economy, the main source of funding and an indicator of the effectiveness of the enterprise [3, 4]. Information about profit is necessary for external and internal users to make reasonable and effective managerial decisions [5-7].

\footnotetext{
* Corresponding author : zakirovaar@mail.ru
} 
One of the key tools for managing the financial performance of enterprises is internal control, aimed at ensuring the safety and efficient use of material, labor and financial resources [8-10]. In addition, internal control of financial results should contribute to the formation of the financial mechanism for sustainable development of the economy of enterprises [11, 12].

The presence or absence of an effectively functioning system of internal control at the enterprise has a significant impact on the success of business development, increase of competitiveness, development of the information system, improvement of the quality of accounting and analytical support of the enterprise management system [13-16].

To achieve the effectiveness of management of the agricultural organization on the basis of the internal control system it is necessary to fulfill the following basic conditions: financial and economic stability of the organization; conformity of the activity of the organization to the accepted mission and strategy; an appropriate level of accuracy and completeness of primary documents and quality of primary information for successful management and making effective managerial decisions; economical use of all types of resources; observance by employees of the organization of the established standards and rules of the internal control system. The internal control system is called to find directions of improvement of activity of the organization, to develop procedures of maximization of profit at a clear distribution of a level of expenses [21-22].

Control is a function of management, which is a set of measures to observe and check the state of the control object, compliance and performance by the managed subject, the management decisions taken to identify deviations from the set parameters and conduct regulatory actions [23-26]. Internal control is a system of intra-organizational activities carried out by management, officials, specially created services in the form of legal, economic, financial, industrial and technical control over the financial and economic activities of structural units and the organization as a whole, regulated by its internal documents [27-29].

In the process of management of the organization the internal control closely interacts with other functions of management process, i.e. interaction and interrelation of control function with other management function is necessarily observed [30-33] (Fig. 1). 


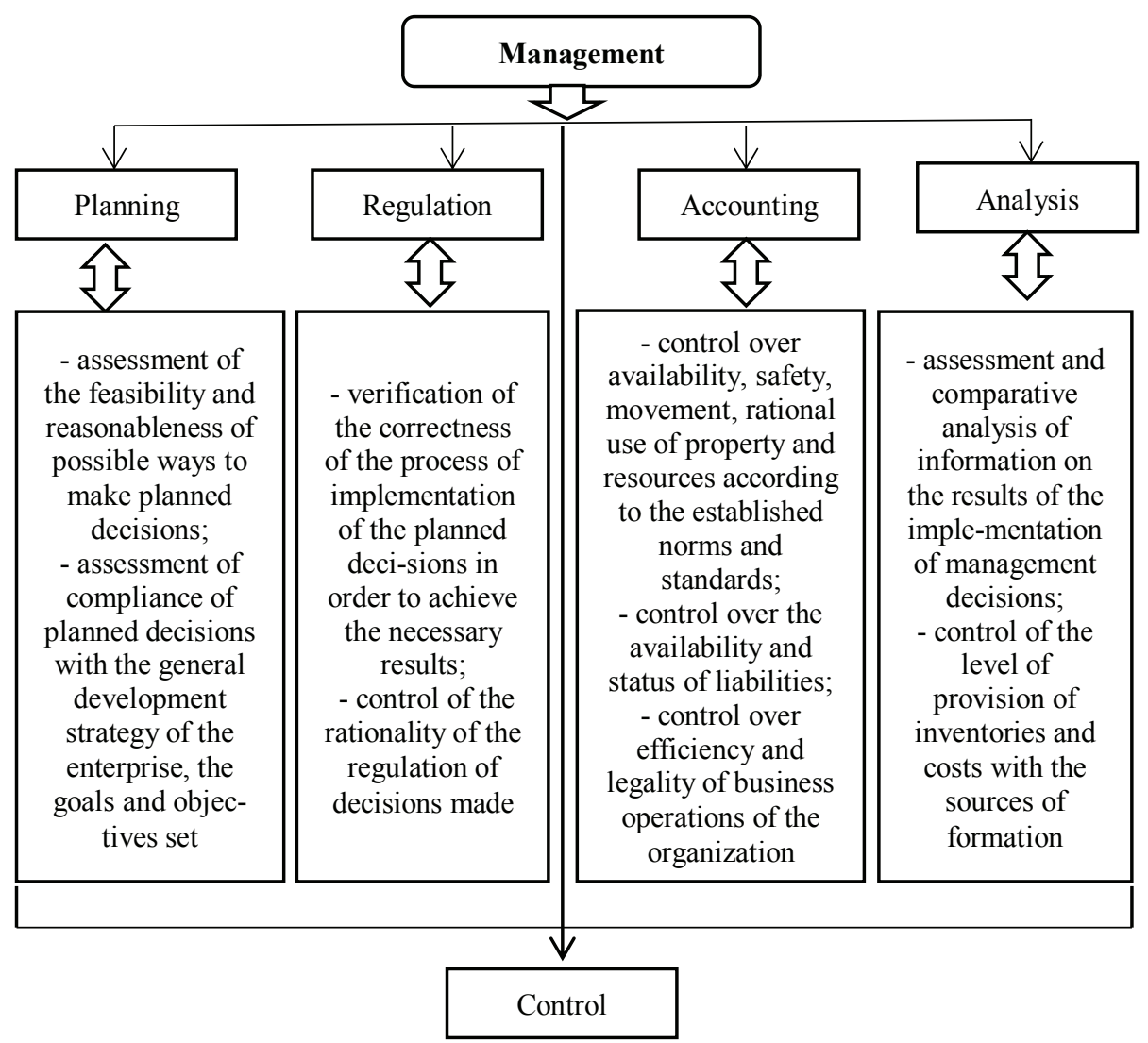

Fig. 1 Interaction and interrelation of control with other functions of management process.

Thus, we see that organization control is an integral part of each function of management process; and at the same time, it is an independent element that provides information support of management process.

\section{Materials and Methods}

An effectively functioning organizational model of internal control includes a set of goals, objectives, principles, subjects, objects, tools, standards of internal control, its regulatory and informational support (Fig. 2). 


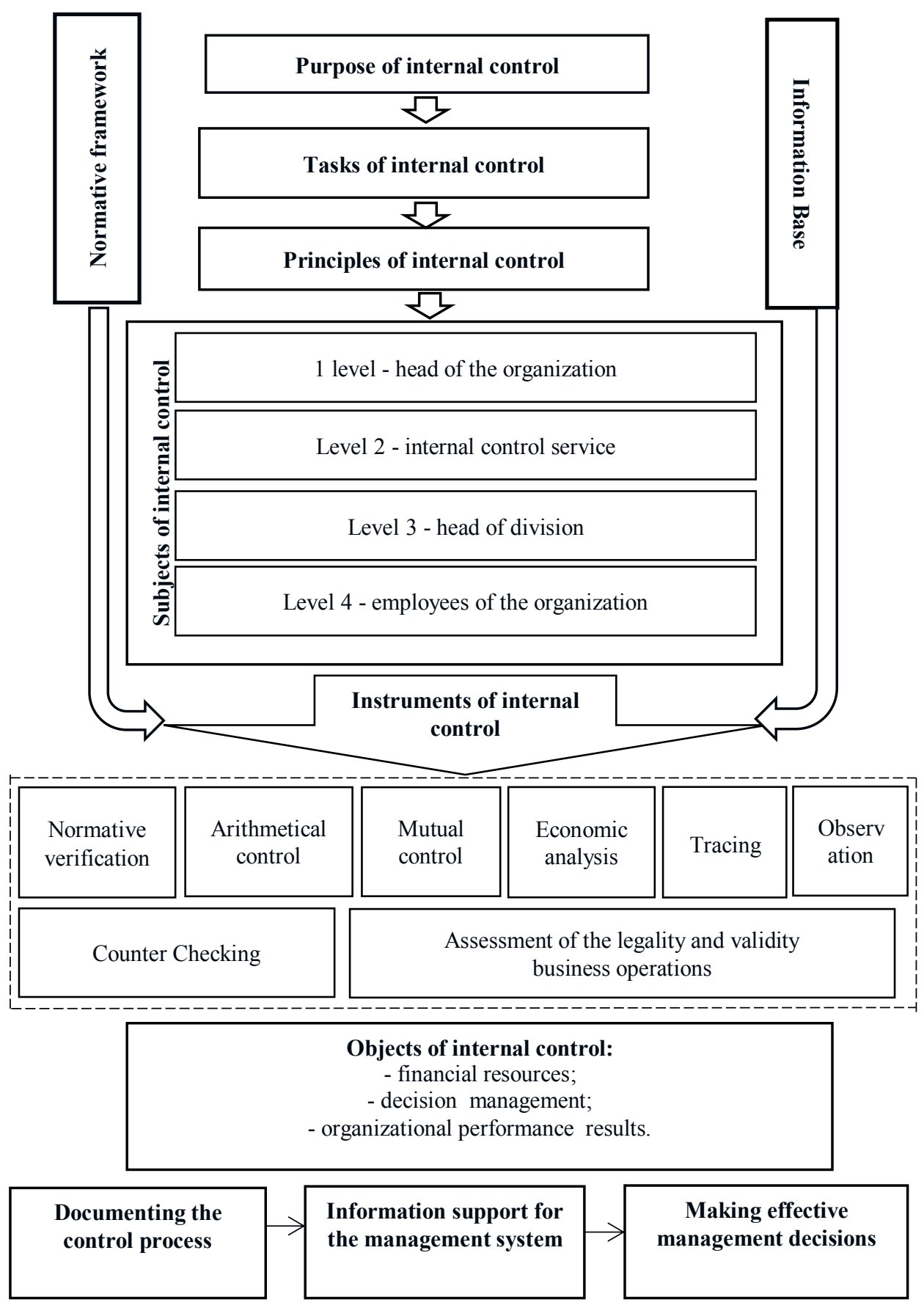

Fig. 2. Conceptual model of internal control.

Internal control is a tool for managing the financial and economic activities of the enterprise that allows you to determine the actual state of the object of control, to identify existing deviations, to determine the causes of their occurrence.

The main purpose of internal control is to minimize economic risks in the process of formation of financial results, establishing the feasibility of business operations performed 
at the enterprise, ensuring the rational use of resources, identifying reserves to improve the effectiveness of business processes, checking the validity of the management decisions.

In our view, the purpose of internal control of financial results can be defined in terms of financial, tax, management and investment approaches (Fig. 3).

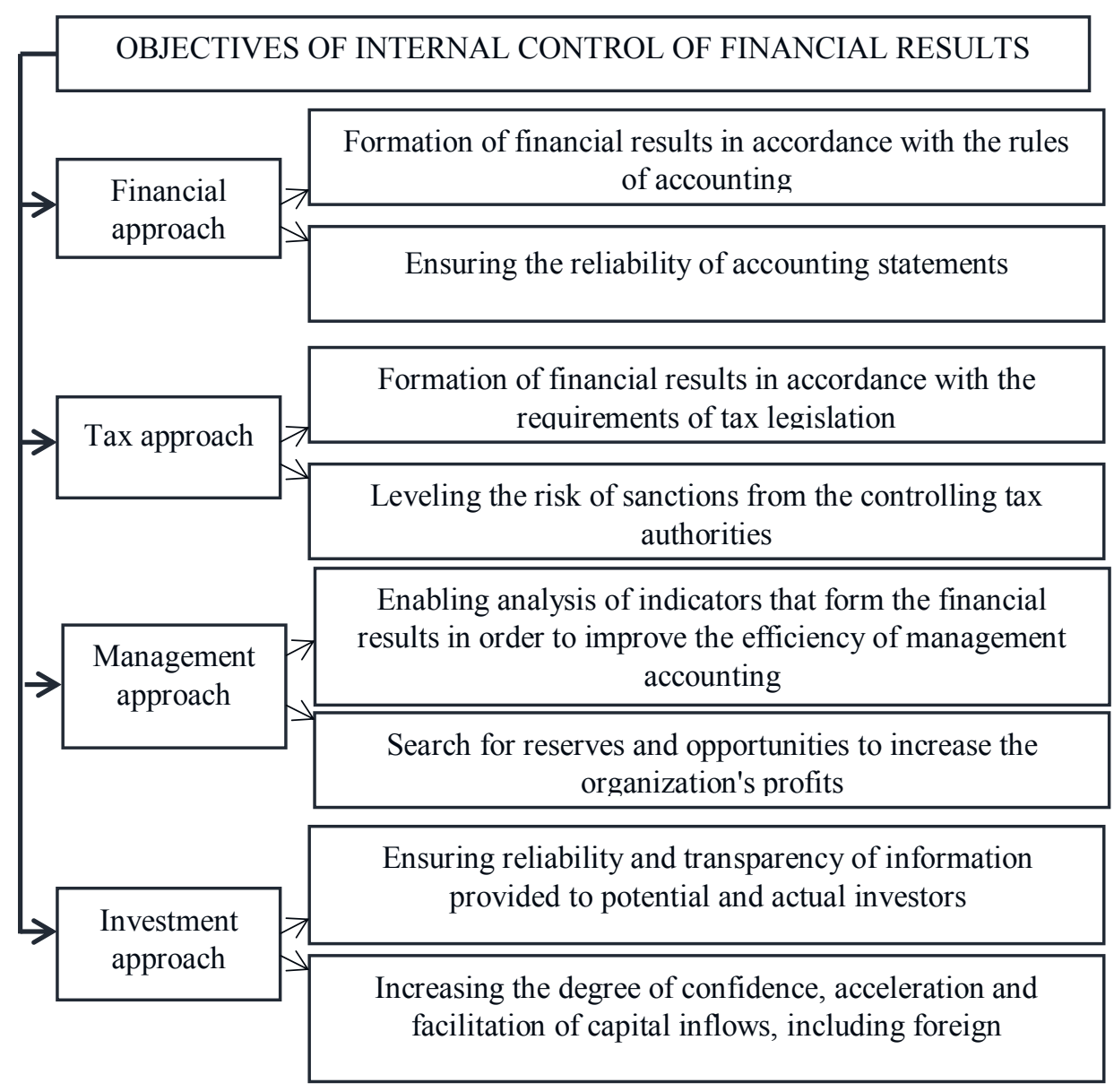

Fig. 3. Objectives of internal control of financial results.

To achieve the goal of internal control of financial results, the following tasks must be accomplished:

- ensured the safety of assets and efficient use of resources of the enterprise;

- ensuring the fulfillment of plans to increase financial results as a result of the effective conduct of business activities;

- ensuring effective prevention, detection and elimination of violations in the process of financial and economic activities of the company;

- effective control procedures were elaborated and introduced, allowing to decrease the risks, which are connected with gaining profit;

- the deviations from the planned parameters were prevented or revealed in time;

- prevention of dishonest actions of employees and third parties that affect the formation of financial results;

- compliance with legal requirements, internal regulations at the formation of financial results is ensured. 
In economic literature the following principles of internal control of financial results are allocated (fig. 4).

\begin{tabular}{|c|c|}
\hline Principle of legality & $\begin{array}{c}\text { ensuring that internal control subjects consistently and } \\
\text { accurately comply with all norms and rules established by } \\
\text { regulatory legal acts }\end{array}$ \\
\hline $\begin{array}{l}\text { Principle of } \\
\text { objectivity }\end{array}$ & $\begin{array}{l}\text { ensuring the reliability of internal control results, which in turn } \\
\text { requires a systematic approach, honesty, integrity, and } \\
\text { impartiality in carrying out controls }\end{array}$ \\
\hline $\begin{array}{r}\text { Principle of } \\
\text { systematicity }\end{array}$ & $\begin{array}{c}\text { regular internal controls, creating a system of controls to manage } \\
\text { the reproduction process }\end{array}$ \\
\hline $\begin{array}{l}\text { Principle of } \\
\text { balance }\end{array}$ & $\begin{array}{l}\text { control functions must be provided with the means to perform } \\
\text { them }\end{array}$ \\
\hline $\begin{array}{l}\text { Principle of } \\
\text { professional } \\
\text { competence }\end{array}$ & $\begin{array}{l}\text { availability of professional specialized training necessary for } \\
\text { effective performance of control functions }\end{array}$ \\
\hline $\begin{array}{l}\text { Principle of } \\
\text { segregation of } \\
\text { duties }\end{array}$ & $\begin{array}{l}\text { effective distribution of functional responsibilities between the } \\
\text { subjects of control }\end{array}$ \\
\hline $\begin{array}{l}\text { Principle of } \\
\text { responsibility }\end{array}$ & $\begin{array}{l}\text { inevitability of legal consequences for violations of legal norms } \\
\text { of current legislation governing the relevant areas of control } \\
\text { activities }\end{array}$ \\
\hline $\begin{array}{l}\text { Principle of } \\
\text { effectiveness }\end{array}$ & $\begin{array}{c}\text { the impact of control on the economy and is expressed through } \\
\text { the effectiveness of measures taken as a result of its } \\
\text { implementation }\end{array}$ \\
\hline $\begin{array}{l}\text { Principle of } \\
\text { rationality }\end{array}$ & $\begin{array}{c}\text { measuring the costs of internal control against the economic } \\
\text { benefits derived from it }\end{array}$ \\
\hline
\end{tabular}

Fig. 4. Principles of internal control.

The principles presented in figure 4 are the criterion of efficiency of the internal control system and are the key condition for its successful functioning.

The normative and legal framework governing internal control of financial results can be presented as a dual system:

Level 1 includes legislative and normative documents regulating accounting and control of financial results;

Level 2 is represented by internal normative documents regulating accounting and control of financial results.

There are two groups of sources that form the information base of internal control of financial results. The first group - internal documents of the organization; the second group 
- external documents of higher legislative and executive authorities, public self-regulatory organizations, credit institutions, international organizations and etc.

The system of subjects of internal control of financial results includes: the head of the organization, the internal control service, heads of departments and employees of the organization (Fig. 5). Figure 5 shows subjects of internal control and their functional duties

\section{The head of the organization}

Reviews the results of the work of the structural subdivision of internal control.

Establishes responsibility for the implementation of the decisions of senior management in the field of internal control.

Considers and approves the plan of measures on elimination of shortcomings of ICS.

\section{Internal Control Service}

Checks compliance of departments and employees' activities with regulatory documents;

Identifies the facts of violations, analyzes the reasons for them and develops recommendations to improve existing and/or introduce new control procedures;

Exercises control over the timely and complete elimination of the revealed violations and shortcomings.

Advises on the improvement of internal controls.

Completes internal control training in accordance with the approved training program

\begin{tabular}{|c|c|}
\hline $\begin{array}{l}\text { Subjec } \\
\text { contro }\end{array}$ & $\begin{array}{l}\text { f internal } \\
\text { financial } \\
\text { ults }\end{array}$ \\
\hline $\begin{array}{l}\text { Heads of departments } \\
\text { Timely identification and analysis of } \\
\text { financial and business risks; } \\
\text { Monitoring of ICS functioning, as well as } \\
\text { self-assessment of the efficiency of control } \\
\text { procedures they perform } \\
\text { Informing management } \\
\text { errors/deficiencies that have led or may } \\
\text { lead to potential negative events; } \\
\text { Executing management decisions, } \\
\text { identifying and managing the impact of } \\
\text { financial and economic risks } \\
\text { Completing internal control training in } \\
\text { accordance with an approved training } \\
\text { program }\end{array}$ & $\begin{array}{l}\text { Employees of the organization } \\
\text { Identification of risks and threats to the } \\
\text { stable operation of production facilities. } \\
\text { Determination of risks of violation of } \\
\text { production technology. } \\
\text { Informing management of errors/failures } \\
\text { that have led or may lead to potential } \\
\text { negative events; } \\
\text { Assessing the ability to maintain } \\
\text { Competitiveness of manufactured products, } \\
\text { identifying risks of loss of business } \\
\text { information on production issues } \\
\text { Completing internal control training in } \\
\text { accordance with an approved training } \\
\text { program }\end{array}$ \\
\hline
\end{tabular}

Fig. 5. Subjects of internal control of financial results.

For effective distribution of powers between subjects of the internal control it is necessary to develop internal documents, regulations on structural divisions, job 
descriptions and other organizational and administrative documents regulating their activity.

Traditionally, the implementation of internal control uses tools and procedures that have been developed by related sciences and together constitute its method. Applying in aggregate all methods of control and analytical system it is possible to study economic processes of the past, present and future.

The internal control toolkit can be presented as a complex mechanism that integrates and coordinates specific tools (methods) of formation of information support of the management system. The tool of the internal control allows practically to realize one or a set of its methods.

The internal control tools may include:

1. Normative inspection. During normative checking the monitoring of normative documents is performed, it is established, whether the provisions of accounting policy in the part of accounting of financial results correspond to the requirements of legislation, deviations from legislation are revealed;

2. Arithmetic check consists in recalculation and verification of correctness of calculations and reflection of final data in accounting. During the arithmetic control of financial performance monetary and quantitative indicators of cost accounting for production and costing of products, works, services, indicators of accounting for the sale of products, works and services and the formation of financial results are checked;

3. Reciprocal control. With mutual control compared two or more documents, which are different in content, executed on the same or a group of interrelated operations. So, under internal control of financial results is verified the correctness of accounting shipped products. In this case mutually control are subject to contracts for the supply of products, documents on the shipment of products, completeness of registration of invoices, as well as whether vacation prices are set correctly;

4. Reciprocal audit. During the on-site audit documents prepared in duplicate and located in different parts of the organization or other organizations are checked. During internal control of financial results during carrying out of counter check it can be revealed reliability and reality of receipt of ready production to the warehouse on the basis of invoices and receiving orders, orders for work performed. In addition, there may be identified cases associated with unacceptance of funds received from other organizations as a result of the sale of finished products, work performed and services rendered. In this case the bills of lading, invoices, documents on receipt of cash are subject to inspection;

5. Economic analysis. This tool of control is used during inspection of financial and economic activity, during which the cost price and profitability of production is analyzed, the financial condition is analyzed; production operations that are unprofitable, the causes of unprofitability or low profitability are revealed;

6. Tracing implies checking separate primary documents, the correctness of their reflection in the registers of analytical and synthetic accounting. During tracing correspondence of accounts is determined and correctness of reflection of business operations in accounting is established;

7. Supervision. During internal control of financial results observation of the accuracy of revenue recognition on the accounting accounts, the accuracy of income classification, the accuracy of allocation of different groups of costs to the cost of products (works, services) and the accuracy of organization of cost accounting and calculation of the cost of products (works, services) is performed;

8. Assessment of the legality and validity of business operations. .By comparing the data contained in the accounting registers with the data in the primary documents, as well as reporting indicators with the data in the accounting registers identify theft, embezzlement and other violations, hidden unreasonable entries in the accounting records. So, using this 
method during internal control of financial results, accounting entries on accounts 20 «Basic production» and 43 «Finished goods» which lead to the increase of balance sheet profit and as a consequence to the fictitious reports on profit plan fulfillment can be revealed.

The next element of conceptual model is objects of internal control of financial results. The objects of internal control can be represented by the results of financial and economic activity of enterprises, ways of decisions management, processes of formation, distribution and use of financial resources,

The information collected in the process of internal control should be drawn up in the form of working documents. Working papers are drawn up at all stages of internal control. They contain information on planning of control work, characterize the content, time limits, volumes and results of the performed procedures, Working documents may contain information on essential provisions on the revealed deviations, risks, errors, questions, allowing to estimate the compliance of the provisions of accounting policy and its compliance with the requirements of regulations.

Results of internal control are the basis of information support of management system for further adoption of management decisions that allow to ensure the effective functioning of the enterprise, its financial stability, competitiveness, safety and effective use of resources of the enterprise,

To make effective management decisions it is necessary to introduce control procedures at each stage of management process (fig. 6).

STUDY

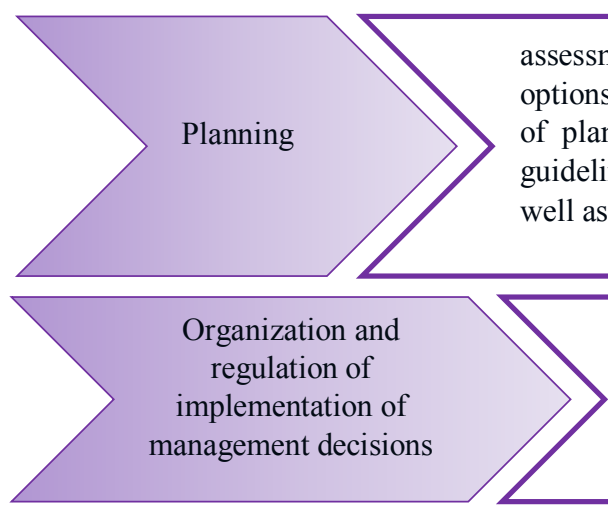

\section{CONTROL PROCEDURES}

assessment of the rationality of possible options for planning decisions; compliance of planning decisions with the established guidelines and the planned benchmarks, as well as the overall strategy.
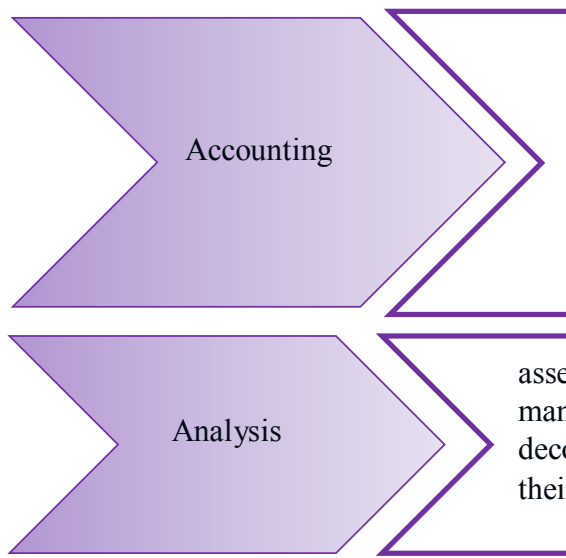

control of the correctness of the process of implementation of the planned decisions to achieve the necessary results

control over: the availability and movement of property; the rational use of resources in accordance with approved norms; the status of issued and received liabilities; the expediency and legality of business operations of the organization.

assessment of information about the results of management decisions based on its decomposition into various components and their correlation with each other.

Fig. 6. Control procedures by stages of the management process. 
Internal control procedures are actions that are carried out at such stages of the management process as planning, organization and regulation of the implementation of management decisions, accounting and analysis, Control procedures should contribute to minimizing the risks that affect the achievement of the objectives of the economic entity.

\section{Results}

Questions of development of the internal control of financial results let's consider by the example of the concrete enterprise - «Meat House «Karlinsky». The system of internal control of the given economic entity is formed by organizational measures, methods, procedures, which are means of effective business dealing, provide property safety, contribute to the identification, correction, error prevention, and also allow timely preparation of reliable accounting statements.

Internal control of financial and economic activities in the «Meat House» Karlinsky «is the head of the branch, the management personnel and chief accountant, as well as managers of responsibility centers, which analyze and evaluate the related production areas and production cycles. The internal control of financial results organized at the «Meat House «Karlinsky» is more of a monitoring nature.

For the system of internal control to function effectively, the set goals and tasks have been achieved, high-quality and timely information is necessary. At the «Meat House» Karlinsky». The main source of information is the information system 1C: Enterprise 8.3. The information that is stored and processed in the information system has a significant impact on management decisions that are made in the branch.

The scale of activity of the organization, its individual characteristics, goals and objectives determine the direction of internal control of financial results (Fig. 7)

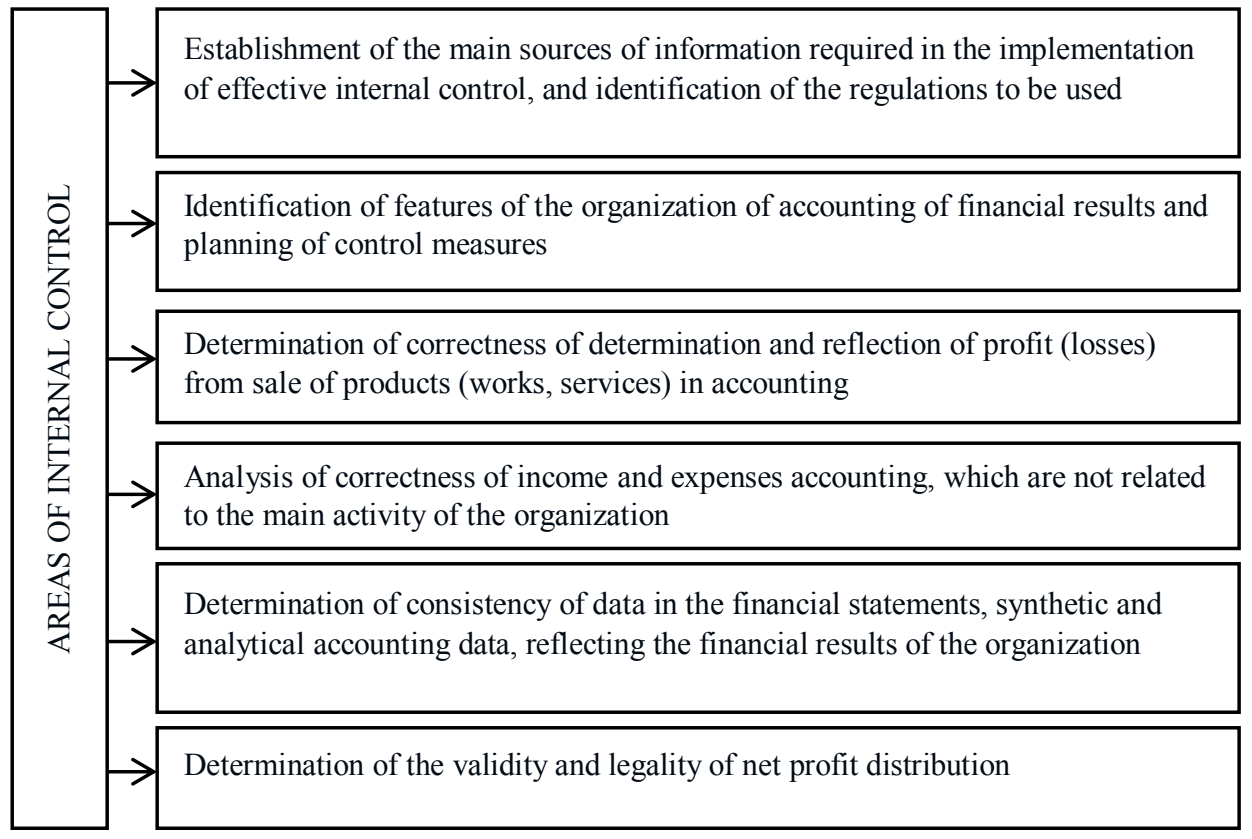

Fig. 7. Directions of the internal control of financial results.

Control procedures performed at the internal control of financial results are divided depending on the stages of control (table 1) 
Table 1. Stages of internal control of financial results.

\begin{tabular}{|c|c|c|c|}
\hline № & Stages & Essence of control procedures & Control instruments \\
\hline \multirow[t]{3}{*}{1} & \multirow{3}{*}{$\begin{array}{l}\text { Preliminary } \\
\text { control }\end{array}$} & Contracts concluded are being studied & Normative verification \\
\hline & & $\begin{array}{l}\text { The reliability of suppliers and } \\
\text { customers is assessed }\end{array}$ & Rating method \\
\hline & & $\begin{array}{l}\begin{array}{l}\text { Reasonableness of prices } \\
\text { established }\end{array}\end{array}$ & Comparison method \\
\hline \multirow[t]{4}{*}{2} & \multirow[t]{4}{*}{ Current control } & $\begin{array}{l}\text { The correctness of primary documents } \\
\text { is checked }\end{array}$ & $\begin{array}{l}\text { Formal verification, } \\
\text { normative verification, } \\
\text { logical verification }\end{array}$ \\
\hline & & $\begin{array}{l}\text { Inspect completeness and accuracy of } \\
\text { income accounting (confirm the facts } \\
\text { of their existence on the basis of } \\
\text { primary documents) }\end{array}$ & Counter reconciliation \\
\hline & & $\begin{array}{l}\text { Verification of the correctness of the } \\
\text { organization of costs and calculating } \\
\text { the cost of products (works, services) }\end{array}$ & $\begin{array}{l}\text { Observation, oral } \\
\text { questioning, analytical } \\
\text { procedures }\end{array}$ \\
\hline & & $\begin{array}{l}\text { Verification of correctness of } \\
\text { reflection of formation of financial } \\
\text { results in accounting and their } \\
\text { documentary validity }\end{array}$ & $\begin{array}{l}\text { Comparison of indicators } \\
\text { contained in AFR and } \\
\text { accounting registers AFS }\end{array}$ \\
\hline \multirow[t]{5}{*}{3} & \multirow[t]{5}{*}{ Follow-up control } & $\begin{array}{l}\text { Risks in the conduct of } \\
\text { Business risks in terms of formation } \\
\text { of financial results }\end{array}$ & Analytical Procedures \\
\hline & & $\begin{array}{l}\text { Identification of violations and } \\
\begin{array}{l}\text { deviations in the accounting and } \\
\text { reporting }\end{array}\end{array}$ & Tracking Mutual control \\
\hline & & $\begin{array}{l}\text { The reality of the revenues from the } \\
\text { sale of products (work, services) } \\
\text { reflected in the statements is } \\
\text { confirmed }\end{array}$ & $\begin{array}{l}\text { Tracking Counter } \\
\text { Reconciliation }\end{array}$ \\
\hline & & $\begin{array}{l}\text { Sanctions for violations committed in } \\
\text { the course of financial and economic } \\
\text { activities and rewards for good faith } \\
\text { performance are determined }\end{array}$ & Normative verification \\
\hline & & $\begin{array}{l}\text { The quality of executed control } \\
\text { procedures is assessed }\end{array}$ & Testing \\
\hline
\end{tabular}

At the first stage of preliminary control the correctness of agreements concluded with counterparties are checked, whether they meet the requirements of legislation and certain circumstances of performed operations. The presence of business risks, in particular the incorrect execution of the package of documents; bankruptcy of the counterparty and, consequently, the recognition as uncollectible of its receivables; unreasonably high or low prices, affecting demand and subsequently the financial result.

Current control, carried out during business operations, involves the examination of the correctness of the primary documents using formal, normative and logical checks. Also at this stage of internal control establish completeness and accuracy of income accounting; correctness of cost accounting and formation of financial results and their documentary registration.

The purpose of subsequent control is an objective assessment of the activities of the enterprise, establishing the legality and appropriateness of the actions of officials on the formation and management of financial performance.

At this stage, using such methods of control as tracing, mutual control and crosschecking identify violations and deviations in the accounting and reporting, and confirm the 
reality of the existence reflected in the reporting of revenue from the sale of products (works, services). In addition, the quality of performed control procedures is assessed by testing.

The initial stage of control activities - planning - implies the development of a general plan of inspection, which specifies the expected scope, schedule, timing of internal control. In addition, in the process of planning a program is developed, which determines the types and sequence of control procedures that need to be implemented to achieve the objectives.

During planning of control measures the following particular principles are taken into account:

1. The principle of comprehensiveness - coordination and interconnection of stages of planning from a preliminary assessment of the scope of the proposed control measures to registration of the results of internal control is ensured;

2. Principle of continuity - related tasks are established for a group of controllers and planning stages are coordinated depending on the terms by related business entities;

3. Principle of optimality - during planning an opportunity of choosing the most optimal control program shall be ensured, on the basis of criteria defined by regulatory acts;

4. Principle of effectiveness - while planning tasks it is necessary to specify exact terms, executors of control measures in order to control in time the effectiveness of inspection;

5. Principle of concreteness - in the program the directions and methods of inspection should be specified for exact determination of terms and executors.

For example, the section of the program of internal control of financial results may contain the following directions:

- evaluation of accounting policies in terms of provisions that determine the process of formation of financial results of the organization;

- control of compliance with the principles and organization of accounting of financial results;

- control of timely and complete recording of financial results;

- to check the documents and registers of accounting of financial results;

- verification of identity of the data contained in the accounting registers and the general ledger;

- inspection of correctness of profit taxation;

- control over correctness of accounting for profit distribution.

6. Principle of reality - control measures allocated in the plan should be determined taking into account the possibility of involvement of human and material resources for verification;

7. Principle of flexibility - the possibility of improving, supplementing and refining the plan drawn up at the beginning of the audit is provided. All changes made to the plan shall be justified and conditioned by specific facts.

At the planning stage the controller should perform the following actions (Fig. 8).

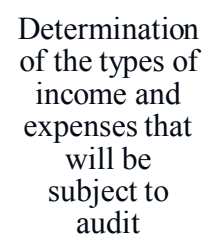
Determination of the types of income and expenses that audit
Determining the nature of verification
Deciding on the method of verification (solid or selective) the organization of accounting and controls for each object of inspection
Selection of control methods applicable to each object of verification

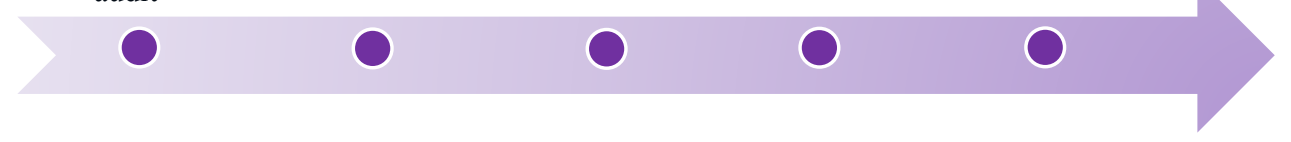

Fig. 8. The main stages of internal control planning. 
The controller determines the objects of audit on the basis of the results of the analysis of revenues, expenses and profits.

Applying analytical procedures at the planning stage, the controller identifies situations that are atypical in the organization's activities and affect the formation of reporting.

In the process of analysis the controller receives information about the main sources and directions of income and expenditure, the sources of profit formation, the factors that influenced the amount and dynamics of financial results

Let's start the analysis of financial results of the "Meat House «Karlinsky» with the general estimation of profit (loss) before taxes in order to evaluate all its activities (table 2).

Table 2. Analysis of the profit (loss) before taxation of the «Karlinsky Meat House» for 2018 - 2019.

\begin{tabular}{|l|c|c|c|c|c|c|}
\hline \multirow{2}{*}{ Indicator name } & \multicolumn{2}{|c|}{$\mathbf{2 0 1 8}$ Year } & \multicolumn{2}{c|}{$\mathbf{2 0 1 9}$ Year } & \multicolumn{2}{c|}{ Defelection } \\
\cline { 2 - 7 } & $\begin{array}{c}\text { Amount. } \\
\text { thous. } \\
\text { rub. }\end{array}$ & $\begin{array}{c}\text { Spec. } \\
\text { weight. } \\
\text { \% }\end{array}$ & $\begin{array}{c}\text { Amount. } \\
\text { thous. } \\
\text { rub. }\end{array}$ & $\begin{array}{c}\text { Spec. } \\
\text { weight. } \\
\text { \% }\end{array}$ & $\begin{array}{c}\text { Absolute. } \\
\text { thous. rub. }\end{array}$ & $\begin{array}{c}\text { Relative. } \\
\%\end{array}$ \\
\hline $\begin{array}{l}\text { Profit (loss) } \\
\text { from sales }\end{array}$ & 2 & 3 & 4 & 5 & $6=4-2$ & $7=6 * 100 / 2$ \\
\hline Other income & 1219 & -2.90 & 7786 & -41.19 & 6567 & 538.71 \\
\hline Other expenses & -4914 & 11.69 & -12017 & 63.58 & -7103 & 144.54 \\
\hline $\begin{array}{l}\text { Profit (loss) } \\
\text { before taxes }\end{array}$ & -42028 & 100.00 & -18901 & 100.00 & 23127 & -55.03 \\
\hline
\end{tabular}

First of all, we can see from Table 2 that the analyzed organization has been carrying out its activity inefficiently for the last 2 years, as evidenced by the fact of making a loss on all types of activities. At the same time in 2019 compared to 2018 there is a decrease in loss before taxation by 23127 thousand rubles or by $55.03 \%$ due to decrease in loss from main activities by $61.73 \%$, increase in other income by 6.4 times.

The vertical analysis of the loss shows that the main part of it is sales loss $(91.21 \%$ in 2018 and $77.62 \%$ in 2019). This indicates that the main cause of the organization's unprofitability is its unprofitable core business.

In order to analyze in detail the financial results of «Meat House «Karlinsky», it is necessary to study the composition of each element of the loss before taxation and the factors that influenced them.

Each element of the pre-tax loss can be divided into first-order factors (loss on sales, other income and expenses) and second-order factors (price, sales volume, cost of sales, management and selling expenses). In our case, the change in loss before taxation is caused by both positive and negative impact of separate factors. Therefore, we will begin our study of the reasons for the change in the loss before taxation in 2019 by examining the 1st order factors - the income and expenses of the «Karlinsky Meat House». For this purpose, we will build separate analytical tables indicating their composition and structure of income and expenses (Table 3.). 
Table 3. Analysis of income of the «Karlinsky Meat House» for 2018 - 2019.

\begin{tabular}{|c|c|c|c|c|c|c|c|}
\hline \multirow[b]{2}{*}{$\begin{array}{c}\text { Indicator } \\
\text { name }\end{array}$} & \multicolumn{2}{|c|}{ For 2018 year } & \multicolumn{2}{|c|}{ For 2019 year } & \multicolumn{2}{|c|}{ Deflection } & \multirow{2}{*}{$\begin{array}{c}\text { Change } \\
\text { in } \\
\text { specific } \\
\text { weight }\end{array}$} \\
\hline & $\begin{array}{l}\text { Amount. } \\
\text { thous.rub }\end{array}$ & $\begin{array}{c}\text { Spec. } \\
\text { weight. } \\
\%\end{array}$ & $\begin{array}{l}\text { Amount. } \\
\text { thous.rub. }\end{array}$ & $\begin{array}{c}\text { Spec. } \\
\text { weight. } \\
\text { \% }\end{array}$ & $\begin{array}{l}\text { Amount. } \\
\text { thous.rub }\end{array}$ & $\begin{array}{l}\text { In } \% \\
\text { ratio }\end{array}$ & \\
\hline 1 & 2 & 3 & 4 & 5 & $6=4-2$ & $7=6 * 100 / 2$ & 8 \\
\hline $\begin{array}{l}\text { Revenue } \\
\text { - total }\end{array}$ & 652131 & 100 & 603350 & 100 & - 48781 & -7.48 & 0.00 \\
\hline Revenue & 650912 & 99.81 & 595564 & 98.71 & -55348 & -8.50 & -1.10 \\
\hline $\begin{array}{l}\text { Other } \\
\text { income }\end{array}$ & 1219 & 0.19 & 7786 & 1.29 & 6567 & 538.71 & 1.10 \\
\hline
\end{tabular}

Based on the data in Table 3, we can say that the branch's income in 2019 decreased by a total of 48781 thousand rubles, or $7.48 \%$, compared to 2018 . This change was most influenced by a decrease in revenue (the change was $-55,348$ thousand rubles in absolute terms, and $-8.50 \%$ in relative terms). Revenue occupies the main part of the total amount of income $(98.71 \%)$.

Collecting all items of revenue by type of activity of the branch into 3 groups, we will make a comparative analysis of the composition and dynamics of revenue by type of activity of the branch for 2018 - 2019, which is shown in Table 4.

Table 4. Analysis of the composition and dynamics of revenue by type of activity of the «Meat House «Karlinsky» for $2018-2019$.

\begin{tabular}{|c|c|c|c|c|c|}
\hline \multirow[b]{2}{*}{ Product name } & \multirow[b]{2}{*}{$\begin{array}{l}\text { 2018. amount. } \\
\text { thousand } \\
\text { rubles. (without } \\
\text { VAT) }\end{array}$} & \multirow{2}{*}{$\begin{array}{c}2019 . \\
\text { amount. } \\
\text { thousand } \\
\text { rubles. } \\
\text { (without } \\
\text { VAT) }\end{array}$} & \multicolumn{3}{|c|}{ Deviation of the value } \\
\hline & & & $\begin{array}{l}\text { Amount. } \\
\text { thous. rub.. }\end{array}$ & $\begin{array}{l}\text { Growth } \\
\text { rate. \% }\end{array}$ & $\begin{array}{c}\% \text { of } \\
\text { previous } \\
\text { year's } \\
\text { revenue }\end{array}$ \\
\hline 1 & 2 & 3 & $4=3-2$ & $5=4 * 100 / 2$ & 6 \\
\hline $\begin{array}{l}\text { 1. Sales of meat } \\
\text { products }\end{array}$ & 621604 & 531634 & - 89970 & -14.47 & -13.87 \\
\hline 1.1 Sausages & 3036 & 5882 & 2846 & 93.76 & 0.44 \\
\hline $\begin{array}{l}1.2 \text { Meat and } \\
\text { smoked meats }\end{array}$ & 475382 & 401246 & - 74137 & -15.60 & -11.43 \\
\hline $\begin{array}{l}\text { 1.3.Kurates. } \\
\text { sausages. } \\
\text { wieners }\end{array}$ & 885 & 1074 & 189 & 21.37 & 0.03 \\
\hline $\begin{array}{l}\text { 1.4 Semi- } \\
\text { finished } \\
\text { products }\end{array}$ & 109180 & 90467 & -18713 & -17.14 & -2.88 \\
\hline $\begin{array}{l}\text { 1.5 Sub- } \\
\text { products }\end{array}$ & 33121 & 32965 & -156 & -0.47 & -0.02 \\
\hline $\begin{array}{l}\text { 2. Realization } \\
\text { of live cattle }\end{array}$ & 17396 & 8136 & -9260 & -53.23 & -1.43 \\
\hline 2.1. CATTLE & 17309 & 7832 & -9478 & -54.75 & -1.46 \\
\hline 2.2 Horses & 86 & 305 & 218 & 252.48 & 0.03 \\
\hline $\begin{array}{l}\text { 3. Rendered } \\
\text { works and } \\
\text { services on the } \\
\text { side }\end{array}$ & 9837 & 520 & -9317 & -94.71 & -1.44 \\
\hline Revenue - total & 648838 & 540290 & -108547 & -16.73 & -16.73 \\
\hline
\end{tabular}


According to the data in Table 4, it can be seen that the reduction in revenue occurred to a greater extent due to changes in the volume of sales of meat products, namely due to the reduction in revenue from sales of meat and smoked meat, which in 2018 was 475,382 thousand rubles, and in 2019 - 401246 thousand rubles, i.e. reduction compared to last year was $15.6 \%$, which led to a decrease in the total revenue of the branch for the analyzed year by $11.43 \%$.

Decreases in revenues from the sale of live cattle and the provision of works and services on the side also had a negative impact on total revenues $(-1.43 \%$ and $-1.44 \%$, respectively).

Next, let's analyze the expenses of the branch; the calculations are presented in Table 5.

Table 5. Analysis of expenses of «Meat House «Karlinsky» for 2018 - 2019.

\begin{tabular}{|c|c|c|c|c|c|c|c|}
\hline \multirow[b]{2}{*}{$\begin{array}{c}\text { Indicator } \\
\text { name }\end{array}$} & \multicolumn{2}{|c|}{ For 2018 year. } & \multicolumn{2}{|c|}{ For 2019 year. } & \multicolumn{2}{|c|}{ Deflection } & \multirow[b]{2}{*}{$\begin{array}{l}\text { Change } \\
\text { in } \\
\text { Specific } \\
\text { Weight }\end{array}$} \\
\hline & $\begin{array}{c}\text { Amount. } \\
\text { thous. } \\
\text { rub. }\end{array}$ & $\begin{array}{c}\text { Specifi } \\
\text { c } \\
\text { weight } \\
\%\end{array}$ & $\begin{array}{c}\text { Amount } \\
\text {. thous. } \\
\text { rub. }\end{array}$ & $\begin{array}{c}\text { Specifi } \\
\text { c } \\
\text { Weight } \\
\%\end{array}$ & $\begin{array}{c}\text { Amount } \\
\text {. thous. } \\
\text { rub. }\end{array}$ & $\begin{array}{c}\text { In \% } \\
\text { ratio }\end{array}$ & \\
\hline 1 & 2 & 3 & 4 & 5 & $6=4-2$ & $\begin{array}{c}7=6 * 10 \\
0 / 2\end{array}$ & 8 \\
\hline $\begin{array}{l}\text { Expenditu } \\
\text { res - total }\end{array}$ & 694159 & 100 & 567073 & 100 & $\begin{array}{c}-127 \\
086\end{array}$ & -18.31 & 0 \\
\hline $\begin{array}{l}\text { Current } \\
\text { expenses } \\
\text { from } \\
\text { ordinary } \\
\text { activities. } \\
\text { including }\end{array}$ & 689245 & 99.29 & 555057 & 97.88 & $\begin{array}{c}-134 \\
188\end{array}$ & -19.47 & -1.41 \\
\hline $\begin{array}{l}1.1 \text { Cost of } \\
\text { sales }\end{array}$ & 665453 & 95.86 & 549559 & 96.91 & $\begin{array}{c}-115 \\
894 \\
\end{array}$ & -17.42 & 1.05 \\
\hline $\begin{array}{l}1.2 \\
\text { Managem } \\
\text { ent } \\
\text { expenses }\end{array}$ & 22023 & 3.17 & 4223 & 0.74 & -17800 & -80.83 & -2.43 \\
\hline $\begin{array}{l}1.3 \\
\text { Commerci } \\
\text { al } \\
\text { expenses }\end{array}$ & 1769 & 0.25 & 1275 & 0.22 & -494 & -27.93 & -0.03 \\
\hline $\begin{array}{l}\begin{array}{l}\text { 2. Other } \\
\text { expenses }\end{array}\end{array}$ & 4914 & 0.71 & 12017 & 2.12 & 7103 & 144.54 & 1.41 \\
\hline
\end{tabular}

Expenses of the branch in the analyzed period, decreased by 127086 thousand rubles in absolute terms and by $18.31 \%$ in relative terms. Simultaneous decrease in income and expenses in 2019, compared to the previous year, led to a decrease in the value of the resulting loss due to the outstripping rate of reduction of expenses over the rate of reduction of income.

Analyzing the structure of the branch expenses, we can conclude that their main part falls on the cost of sales (in $2018-95.86 \%$, in $2019-96.91 \%$ ). It is worth noting that in the reporting year the share of management expenses in the total amount of expenses decreased by 2.43 p.p. due to an increase in the share of other expenses (by 1.41 p.p.) and cost of sales (by 1.05 p.p.).

According to the results of the analysis of expenses it has been revealed that the largest share of all expenses is occupied by the value of the full cost price (current expenses). In this connection it is necessary to study the composition, structure and dynamics of current 
expenses with the purpose of making administrative decisions on cost optimization. The composition and structure of current costs are shown in Figure 9.

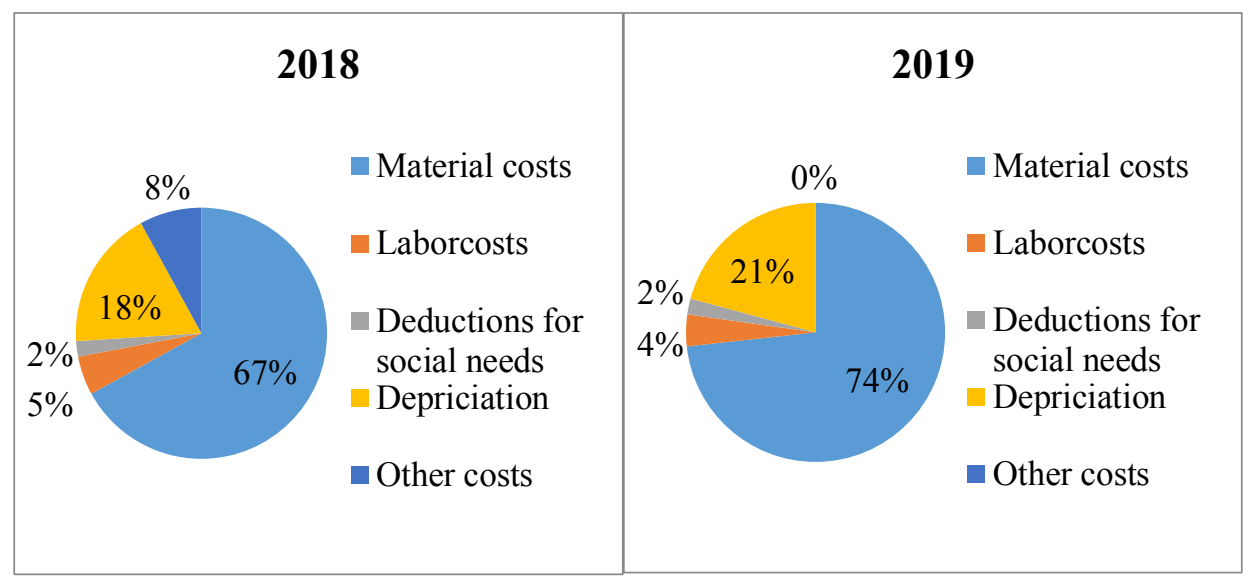

Fig. 9. Composition and structure of current expenses of Karlinsky Meat House for 2018-2019.

Figure 9 shows the composition of costs that form the current costs of Karlin Meat House. Thus, the main share of current expenses is material costs (in 2018 - 67\%, in 2019 $74 \%$ ), followed by depreciation charges (in $2018-18 \%$, in $2019-21 \%$ ) and labor costs (in $2018-5 \%$, in $2019-4 \%$ ). The analysis of current expenses structure allows to conclude that in the analyzed year the share of each element of income from usual types of activity has changed, therefore it is necessary to carry out the horizontal analysis in order to determine the character of their changes. For this purpose let's make the analytical table indicating the structure of current expenses and dynamics of their changes (table 6).

Table 6. Horizontal analysis of current expenses of «Meat House «Karlinsky» for 2018 - 2019.

\begin{tabular}{|l|c|c|c|c|c|}
\hline Indicator name & $\begin{array}{c}\text { For 2018. } \\
\text { thous. } \\
\text { rub. }\end{array}$ & $\begin{array}{c}\text { For } \\
\mathbf{2 0 1 9 .} \\
\text { thous. } \\
\text { rub. }\end{array}$ & Defelction+/- & $\begin{array}{c}\text { Growth } \\
\text { rate. \% }\end{array}$ & $\begin{array}{c}\text { Effect of the } \\
\text { change in the } \\
\text { indicator on } \\
\text { the total } \\
\text { expenditures.\% }\end{array}$ \\
\hline \multicolumn{1}{|c|}{1} & 2 & 3 & $4=3-2$ & $5=4 * 100 / 2$ & 6 \\
\hline Tangible costs & 463122 & 410977 & -52145 & -11.26 & -7.57 \\
\hline Labor costs & 33175 & 22283 & -10892 & -32.83 & -1.58 \\
\hline $\begin{array}{l}\text { Social } \\
\text { contributions }\end{array}$ & 9939 & 7037 & -2902 & -29.20 & -0.42 \\
\hline Depreciation & 124804 & 112956 & -11848 & -9.49 & -1.72 \\
\hline Other expenses & 57067 & 1136 & -55931 & -98.01 & -8.11 \\
\hline $\begin{array}{l}\text { Total by } \\
\text { elements }\end{array}$ & 688107 & 554389 & -133718 & -19.43 & -19.40 \\
\hline $\begin{array}{l}\text { Changes in } \\
\text { work-in- } \\
\text { progress. } \\
\text { finished goods. } \\
\text { etc. (increase [-]. } \\
\text { decrease [+]): }\end{array}$ & 1139 & 668 & -471 & -41.35 & -0.07 \\
\hline $\begin{array}{l}\text { Total expenses } \\
\text { for ordinary } \\
\text { activities }\end{array}$ & 689246 & 555057 & -134189 & -19.47 & -19.47 \\
\hline
\end{tabular}


As shown in Table 6, expenses on ordinary activities decreased by 134189 thousand rubles in 2019. (by 19.47\%). The change in all items of current expenses, namely their reduction, led to a decrease in the total amount of expenses. Among the current expense items, the largest change in 2019 was in other expenses, with a $98.01 \%$ decrease, resulting in an $8.11 \%$ decrease in current expenses. Also, the greatest impact on the change in operating expenses was a decrease in material costs by $11.26 \%$, which resulted in a decrease of $7.57 \%$ in total expenses for ordinary activities compared to the previous year.

Thus, based on our summary analysis of the financial results of the investigated branch for 2019, the following conclusions can be made, which will determine the main directions of internal control:

- «Meat House «Karlinsky» for the last two years inefficiently operates, as evidenced by the fact of obtaining a loss on all types of activities;

- In 2019 there is a simultaneous reduction in income and expenses of the branch. However, the excess of the rate of decrease in expenses over the rate of decrease in income led to a decrease in the loss in the analyzed year;

- the change in income was more influenced by the decrease in income from ordinary activities, which was most affected by the decrease in sales of meat and smoked meats;

- the amount of the branch's expenses decreased to a greater extent in 2019 due to a decrease in expenses from ordinary activities, which was more influenced by a decrease in other and material expenses.

Also, when planning the internal control of financial results, the methods of verification for each area of control are determined. Revenues and expenses arising as a result of atypical or risky operations are checked on a continuous basis. In addition, income and expenses for which the number of elements of controlled population is insufficient to use sampling are checked on a continuous basis.

Due to the large volume of transactions related to the formation of financial results in the «Meat House» Karlinsky» should apply a combined method of control measures that combines a continuous and sample method verification.

Continuous verification allows to reveal the most risky spheres of activity, for example, operations with suppliers, at interaction with which facts of infringement of contract obligations, untimely granting of primary documents, etc. appeared earlier.

Having carried out a comprehensive analysis of the object of inspection, the controller develops an internal control program, which determines the direction and intensity of control activities (Table 7).

Table 7. Internal Control Working Document (ICWD) «Internal control program of financial results.

\begin{tabular}{|c|c|c|c|c|c|c|}
\hline $\begin{array}{l}\text { Area of } \\
\text { Internal } \\
\text { Control }\end{array}$ & $\begin{array}{l}\text { Normative } \\
\text { base }\end{array}$ & $\begin{array}{c}\text { Source of } \\
\text { information }\end{array}$ & $\begin{array}{l}\text { Control } \\
\text { period }\end{array}$ & $\begin{array}{c}\text { Controller' } \\
\text { s name }\end{array}$ & $\begin{array}{c}\text { Nature of } \\
\text { verification }\end{array}$ & $\begin{array}{l}\text { Control } \\
\text { Procedure }\end{array}$ \\
\hline $\begin{array}{l}1 . \\
\text { Verification } \\
\text { of } \\
\text { accounting } \\
\text { policies in } \\
\text { terms of } \\
\text { accounting } \\
\text { for financial } \\
\text { results }\end{array}$ & $\begin{array}{l}\text { Accounting } \\
\text { Regulation } 9 / 99 \\
\text { «Income of the } \\
\text { organization», } \\
\text { Accounting } \\
\text { Regulation } \\
10 / 99 \\
\text { «Expenses of } \\
\text { the } \\
\text { organization», } \\
\text { Accounting } \\
\text { Regulation } \\
18 / 02 \\
\text { «Accounting } \\
\text { for corporate } \\
\text { income tax }\end{array}$ & $\begin{array}{l}\text { accounting } \\
\text { policy order }\end{array}$ & $\begin{array}{l}10.02 . \\
2020\end{array}$ & $\begin{array}{l}\text { Ivanov } \\
\text { A.A. }\end{array}$ & continuous & $\begin{array}{l}\text { Formal } \\
\text { verification, } \\
\text { normative } \\
\text { verification }\end{array}$ \\
\hline
\end{tabular}




\begin{tabular}{|c|c|c|c|c|c|c|}
\hline & calculations»» & & & & & \\
\hline $\begin{array}{l}\text { 2. Checking } \\
\text { the } \\
\text { correctness } \\
\text { of the } \\
\text { formation of } \\
\text { the cost } \\
\text { price }\end{array}$ & $\begin{array}{l}\text { Accounting } \\
\text { Regulation 4/99 } \\
\text { «Accounting } \\
\text { Reports», } \\
\text { Accounting } \\
\text { Regulation } \\
\text { 10/99 } \\
\text { «Expenses of } \\
\text { the } \\
\text { organization», } \\
\text { Plan of } \\
\text { accounts for } \\
\text { financial and } \\
\text { economic } \\
\text { activities of } \\
\text { organizations } \\
\text { and instructions } \\
\text { for its } \\
\text { application }\end{array}$ & $\begin{array}{l}\text { order on } \\
\text { accounting } \\
\text { policy, } \\
\text { registers of } \\
\text { synthetic } \\
\text { and } \\
\text { analytical } \\
\text { accounting, } \\
\text { reporting }\end{array}$ & $\begin{array}{l}11- \\
12.02 . \\
2020\end{array}$ & $\begin{array}{l}\text { Petrov } \\
\text { V.M. }\end{array}$ & selective & $\begin{array}{l}\text { Formal } \\
\text { verification, } \\
\text { normative } \\
\text { verification, } \\
\text { analytical } \\
\text { verification, } \\
\text { observation } \\
\text {, oral } \\
\text { questioning } \\
\text {, inspection }\end{array}$ \\
\hline $\begin{array}{l}\text { 3. Checking } \\
\text { the } \\
\text { correctness } \\
\text { of revenue } \\
\text { recognition }\end{array}$ & $\begin{array}{l}\text { Accounting } \\
\text { Regulation } 9 / 99 \\
\text { «Income of the } \\
\text { organization», } \\
\text { Plan of } \\
\text { accounts for } \\
\text { financial and } \\
\text { economic } \\
\text { activities of } \\
\text { organizations } \\
\text { and instructions } \\
\text { for its } \\
\text { application }\end{array}$ & $\begin{array}{l}\text { order on } \\
\text { accounting } \\
\text { policy, } \\
\text { product } \\
\text { supply } \\
\text { contracts, } \\
\text { primary } \\
\text { documents, } \\
\text { accounting } \\
\text { registers, } \\
\text { reports }\end{array}$ & $\begin{array}{l}13- \\
14.02 . \\
2020\end{array}$ & $\begin{array}{l}\text { Petrov } \\
\text { V.M. }\end{array}$ & selective & $\begin{array}{l}\text { formal } \\
\text { verification, } \\
\text { normative } \\
\text { verification, } \\
\text { traceability, } \\
\text { cross- } \\
\text { checking, } \\
\text { confirmatio } \\
\text { n, } \\
\text { inspection }\end{array}$ \\
\hline $\begin{array}{l}\text { 4. Checking } \\
\text { the } \\
\text { correctness } \\
\text { of analytical } \\
\text { and } \\
\text { synthetic } \\
\text { accounting } \\
\text { of financial } \\
\text { results from } \\
\text { ordinary } \\
\text { activities }\end{array}$ & $\begin{array}{l}\text { Plan of } \\
\text { accounts for } \\
\text { financial and } \\
\text { economic } \\
\text { activities of } \\
\text { organizations } \\
\text { and instructions } \\
\text { for its } \\
\text { application }\end{array}$ & $\begin{array}{l}\text { order on } \\
\text { accounting } \\
\text { policy, } \\
\text { registers of } \\
\text { synthetic } \\
\text { and } \\
\text { analytical } \\
\text { accounting, } \\
\text { primary } \\
\text { documents } \\
\text { on account } \\
90\end{array}$ & $\begin{array}{l}17.02 . \\
2020\end{array}$ & $\begin{array}{l}\text { Ivanov } \\
\text { A.A. }\end{array}$ & selective & $\begin{array}{l}\text { formal } \\
\text { check, } \\
\text { normative } \\
\text { check, } \\
\text { arithmetic } \\
\text { check }\end{array}$ \\
\hline $\begin{array}{l}\text { 5. Checking } \\
\text { the } \\
\text { correctness } \\
\text { of } \\
\text { accounting } \\
\text { of other } \\
\text { income and } \\
\text { expenses }\end{array}$ & $\begin{array}{l}\text { Accounting } \\
\text { Regulation } 9 / 99 \\
\text { «Income of the } \\
\text { organization», } \\
\text { Accounting } \\
\text { Regulation } \\
10 / 99 \\
\text { «Expenses of } \\
\text { the } \\
\text { organization» }\end{array}$ & $\begin{array}{l}\text { order on } \\
\text { accounting } \\
\text { policy, } \\
\text { registers of } \\
\text { synthetic } \\
\text { and } \\
\text { analytical } \\
\text { accounting, } \\
\text { primary } \\
\text { documents }\end{array}$ & $\begin{array}{l}18.02 \\
2020\end{array}$ & $\begin{array}{l}\text { Petrov } \\
\text { V.M. }\end{array}$ & solid & $\begin{array}{l}\text { formal } \\
\text { varification, } \\
\text { regulatory } \\
\text { review, } \\
\text { counter } \\
\text { reconciliati } \\
\text { on }\end{array}$ \\
\hline $\begin{array}{l}\text { 6. Checking } \\
\text { the } \\
\text { correctness } \\
\text { of analytical } \\
\text { and } \\
\text { synthetic } \\
\text { accounting } \\
\text { of other } \\
\text { income and }\end{array}$ & $\begin{array}{l}\text { Plan of } \\
\text { accounts for } \\
\text { financial and } \\
\text { economic } \\
\text { activities of } \\
\text { organizations } \\
\text { and instructions } \\
\text { for its } \\
\text { application }\end{array}$ & $\begin{array}{l}\text { order on } \\
\text { accounting } \\
\text { policy, } \\
\text { registers of } \\
\text { synthetic } \\
\text { and } \\
\text { analytical } \\
\text { accounting, } \\
\text { primary }\end{array}$ & $\begin{array}{l}19.02 . \\
2020\end{array}$ & $\begin{array}{l}\text { Petrov } \\
\text { V.M. }\end{array}$ & solid & $\begin{array}{l}\text { formal } \\
\text { verification, } \\
\text { normative } \\
\text { verification, } \\
\text { arithmetic } \\
\text { check }\end{array}$ \\
\hline
\end{tabular}




\begin{tabular}{|c|c|c|c|c|c|c|}
\hline expenses & & $\begin{array}{l}\text { documents } \\
\text { on account } \\
91\end{array}$ & & & & \\
\hline $\begin{array}{l}\text { 7. Checking } \\
\text { the accuracy } \\
\text { of income } \\
\text { tax accrual } \\
\text { and } \\
\text { accounting }\end{array}$ & $\begin{array}{l}\text { Tax Code of } \\
\text { the Russian } \\
\text { Federation } \\
\text { (Chapter 25), } \\
\text { Accounting } \\
\text { Regulation } \\
18 / 02 \\
\text { "Accounting } \\
\text { for corporate } \\
\text { income tax } \\
\text { calculations», } \\
\text { Plan of } \\
\text { accounts for } \\
\text { financial and } \\
\text { economic } \\
\text { activities of } \\
\text { organizations } \\
\text { and instructions } \\
\text { for its } \\
\text { application }\end{array}$ & $\begin{array}{l}\text { an order on } \\
\text { accounting } \\
\text { policy, tax } \\
\text { accounting } \\
\text { registers }\end{array}$ & $\begin{array}{l}20.02 . \\
2020\end{array}$ & $\begin{array}{l}\text { Ivanov } \\
\text { A.A. }\end{array}$ & solid & $\begin{array}{l}\text { formal } \\
\text { verification, } \\
\text { normative } \\
\text { verification, } \\
\text { arithmetic } \\
\text { verification, } \\
\text { confirmatio } \\
\text { n, and } \\
\text { counter } \\
\text { reconciliati } \\
\text { on. }\end{array}$ \\
\hline $\begin{array}{l}\text { 8. Checking } \\
\text { the } \\
\text { correctness } \\
\text { of the } \\
\text { formation of } \\
\text { indicators of } \\
\text { the } \\
\text { statement of } \\
\text { financial } \\
\text { results }\end{array}$ & $\begin{array}{l}\text { Accounting } \\
\text { Regulation 4/99 } \\
\text { «Accounting } \\
\text { Reports» }\end{array}$ & $\begin{array}{l}\text { Order on } \\
\text { accounting } \\
\text { policy, } \\
\text { general } \\
\text { ledger, } \\
\text { registers of } \\
\text { synthetic } \\
\text { and } \\
\text { analytical } \\
\text { accounting }\end{array}$ & $\begin{array}{l}21.02 . \\
2020\end{array}$ & $\begin{array}{l}\text { Ivanov } \\
\text { A.A. }\end{array}$ & solid & $\begin{array}{l}\text { formal } \\
\text { verification, } \\
\text { normative } \\
\text { verification, } \\
\text { arithmetic } \\
\text { verification, } \\
\text { validation, } \\
\text { inspection }\end{array}$ \\
\hline
\end{tabular}

The offered form of the program of internal control of financial results defines directions and intensity of control measures, promotes their effective and timely conducting.

At the initial stage of internal control the financial results from usual types of activity are examined in the following directions:

- documentary registration of transactions is inspected, as well as the composition and structure of sales revenues;

- there is an arithmetic check of sales proceeds formation;

- inspection of the organization of tax accounting of income.

The documents that confirm receipt of proceeds from sale, in particular waybills, invoices, etc. are subject to mandatory control. Hereby it is checked up completeness and correctness of registration of documents, filling in of all necessary details (formal inspection); legality of operations and logical connection of separate indicators (inspection in essence).

We suggest drawing up the results of the primary accounting check by means of an internal control working document (Table 8). 
Table 8. Internal Control Working Document (ICWD) «Checking the execution of primary documents».

\begin{tabular}{|c|c|c|c|c|c|c|}
\hline \multirow{2}{*}{$\begin{array}{l}\text { Title of the } \\
\text { document }\end{array}$} & \multirow{2}{*}{$\begin{array}{c}\text { Content of } \\
\text { the } \\
\text { operation }\end{array}$} & \multicolumn{2}{|c|}{$\begin{array}{c}\text { Corresponding } \\
\text { account }\end{array}$} & \multirow{2}{*}{$\begin{array}{l}\text { Amount, } \\
\text { rubles. }\end{array}$} & \multirow{2}{*}{$\begin{array}{c}\text { Control } \\
\text { Procedure }\end{array}$} & \multirow{2}{*}{ Remarks } \\
\hline & & Debit & Credit & & & \\
\hline $\begin{array}{l}\text { Commodity } \\
\text { way bill }\end{array}$ & $\begin{array}{l}\text { Recognized } \\
\text { cash } \\
\text { proceeds } \\
\text { from product } \\
\text { sales }\end{array}$ & $62^{*}$ & $90-1^{*}$ & 234000 & $\begin{array}{l}\text { Formal } \\
\text { verification }\end{array}$ & $\begin{array}{l}\text { Payment } \\
\text { date } \\
\text { missing }\end{array}$ \\
\hline $\begin{array}{l}\text { Accounting } \\
\text { statement, } \\
\text { calculation }\end{array}$ & $\begin{array}{l}\text { Recorded the } \\
\text { cost of sales }\end{array}$ & $90-2^{*}$ & $43-1^{*}$ & 214000 & $\begin{array}{l}\text { Arithmetic } \\
\text { verification }\end{array}$ & $\begin{array}{l}\text { Incorrect } \\
\text { amount } \\
\text { shown }\end{array}$ \\
\hline
\end{tabular}

*62 « Settlements with buyers and customers »;

90-1 «Revenue»;

$90-2$ «Cost of sales»

43-1 «Ready products»

In this document, the controller, on the basis of primary accounting data, reflects the identified deviations in the preparation of primary documents.

In particular, the name and number of the document being audited; the content of the transaction, which is recorded in the document; the correspondence of accounts and the amount according to the accounting and control data; control procedures applied during the audit; comments to be eliminated during the implementation of decisions on the results of the audit.

Control of cash flow arising from sales of products, works and services, as well as from other activities, checking the timeliness of receipt of payment under contracts is carried out on the basis of filling out the proposed working document (Table 9).

Table 9. Internal Control Working Document (ICWD) «Checking the timeliness of receipt of payment under contracts».

\begin{tabular}{|c|c|c|c|c|c|c|c|}
\hline 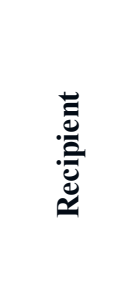 & 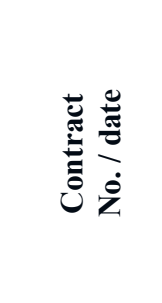 & 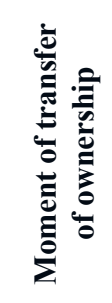 & 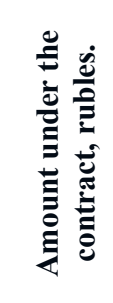 & 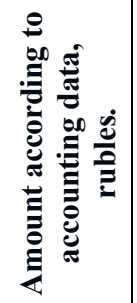 & 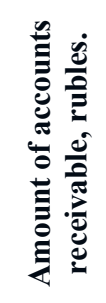 & 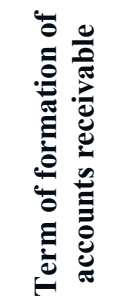 & 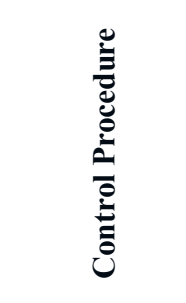 \\
\hline $\begin{array}{l}\text { LLC } \\
\text { «New } \\
\text { Way» }\end{array}$ & $\begin{array}{c}06.06 .2019 \\
\text { № } 1112\end{array}$ & $\begin{array}{l}\text { At the } \\
\text { time of } \\
\text { product } \\
\text { transfer }\end{array}$ & 178800 & 178800 & - & - & $\begin{array}{c}\text { Cross- } \\
\text { reconciliation } \\
\text { Mutual } \\
\text { control }\end{array}$ \\
\hline $\begin{array}{c}\text { LLC } \\
\text { «Mega» }\end{array}$ & $\begin{array}{c}12.08 .2019 \\
\text { № } 1128\end{array}$ & $\begin{array}{l}\text { At the } \\
\text { time of } \\
\text { product } \\
\text { transfer }\end{array}$ & 312400 & 302400 & 10000 & $\begin{array}{l}\text { Up to } \\
\text { three } \\
\text { months }\end{array}$ & $\begin{array}{c}\text { Cross- } \\
\text { reconciliation } \\
\text { Mutual } \\
\text { control }\end{array}$ \\
\hline
\end{tabular}

When it is used, it is possible to identify the formation of accounts receivable for each counterparty in a timely manner and to prevent the emergence of doubtful and overdue accounts receivable.

Special control in the branch «Meat House» Karlinsky» should be subject to operations for the return of goods and shipped products. 
The basis for determining the proceeds of the return of finished products are primary documents that confirm its return by the buyer. Particular attention should be paid by the controller to studying the terms of the contract with counterparties in terms of the transfer of ownership of the products from the seller to the buyer. This affects the reflection of the shipment of finished products and the amount of financial results in the accounting.

During control should be thoroughly checked the facts connected with accrual of fines, penalties, forfeits, which are allowed as a result of nonfulfillment of contractual obligations. The reasons for their occurrence should be studied and the guilty officials should be identified in order to compensate the losses and prevent their occurrence.

In addition, the facts of fulfillment of obligations by the parent organization to the tax authorities should be checked.

To establish the reliability of indicators of financial results from sales it is necessary to check the correctness of accounting for production costs and calculating the cost of production. Verification of the correctness of the formation of the cost of production is carried out on the basis of data contained in the registers of analytical and synthetic accounting of material, labor and cash resources, as well as data in the general ledger of cost accounting.

To confirm the accuracy of registration and reflection of accounting costs it should be found out whether each type of costs assigned to the cost of production, whether the costs are correctly delimited by the objects of accounting and accounting periods, whether the correspondence of accounts regulatory documents.

To check if the costs are legally attributed to the cost of production, you should also take into account the provisions of Chapter 25 of the Tax Code RF. Certain types of costs can be taken into account for income tax purposes within the established norms.

Checking the accuracy of accounting of other income and expenses, which are reflected in the 91 account, the controller should establish how fully they are reflected in the accounting and reporting, as well as check whether income and expenses are calculated correctly for tax purposes.

The following procedures are used to verify other expenses and income:

- primary documents are checked;

- checking whether expenses are correctly attributed to a certain reporting period;

- the data accumulated in the income and expense accounts are analyzed.

\section{Discussion}

Setting up an effective system of internal control requires the development of an intracompany standard «Regulations on the internal control system», which should define:

- objectives, area, rules, methods of activity of the service, its place in the organizational structure of the enterprise, tasks, rights and duties;

- the procedure for providing information on the results of an audit by the internal control service to the head and executive body;

- the conditions and procedure for the provision by the internal control service of information about cases that hinder the effective functioning of the internal control service;

- responsibility of the head of the internal control service for the proper performance of their duties;

- conditions and the order of coordination of activity of the Internal Control Service and structural subdivisions and workers of the agricultural organization, and also the order of rendering of consulting services by it at realization of current activity of the organization

- conditions of operative granting to the service of internal control of the information on activity of the agricultural organization, accepted decisions and local normative legal acts 
of the organization and other questions which are required for the service of internal control for effective performance of its functions;

- conditions of estimation of efficiency and productivity of existing internal control at the enterprise.

The internal control system should be assessed by the head of the organization or an internal auditor at least once a year in order to determine the effectiveness and efficiency of the existing internal controls and, based on that, to make necessary changes. For the purpose of evaluation of efficiency and effectiveness of the existing internal control of financial results at the «Meat House «Karlinsky» we have conducted a survey of employees of accounting department by the test composed by us in advance.

A possible list of test questions to assess the system of internal control of financial results of the «Meat House «Karlinsky» is presented in Table 10, and it is necessary to note that by calculating the number of «yes» answers to the total number of test questions as a percentage, we can conclude on the effectiveness of internal control. It is considered that if the number of positive answers is within $40-60 \%$, the assessment of the internal control system of financial results can be defined as average; if the results are less than $40 \%$ or more than $60 \%$, the level of control is qualified as low or high, respectively.

Table 10. Testing of the internal control system of formation of financial results.

\begin{tabular}{|c|c|c|c|c|}
\hline No & Content of the question & Yes & No & Score \\
\hline 1 & $\begin{array}{l}\text { Have job descriptions been developed for employees of the } \\
\text { financial and accounting service? }\end{array}$ & $\mathrm{X}$ & & 1 \\
\hline 2 & Is the revenue reflected on account 90 «Sales»? & $\mathrm{X}$ & & 1 \\
\hline 3 & Has the organization developed a workflow schedule? & $\mathrm{X}$ & & 1 \\
\hline 4 & Is the workflow schedule being followed? & $\mathrm{X}$ & & 1 \\
\hline 5 & $\begin{array}{l}\text { Does the organization's accounting policy indicate the order } \\
\text { of revenue recognition? }\end{array}$ & $\mathrm{X}$ & & 1 \\
\hline 6 & Is value added tax calculated on the company's revenue? & $\mathrm{X}$ & & 1 \\
\hline 7 & $\begin{array}{l}\text { Is there a checking for arithmetical errors in the calculation } \\
\text { of figures in the accounting records? }\end{array}$ & $\mathrm{X}$ & & 1 \\
\hline 8 & $\begin{array}{l}\text { Is there a separate accounting of revenues and costs when } \\
\text { performing several types of activities? }\end{array}$ & $\mathrm{X}$ & & 1 \\
\hline 9 & $\begin{array}{l}\text { Have orders been created, establishing the range of persons } \\
\text { with certain rights in the field of allocation of production } \\
\text { costs? }\end{array}$ & $\mathrm{X}$ & & 1 \\
\hline 10 & $\begin{array}{l}\text { Is the analysis of contracts with counterparties for } \\
\text { compliance with regulations of the Russian Federation } \\
\text { performed? }\end{array}$ & $\mathrm{X}$ & & 1 \\
\hline 11 & $\begin{array}{l}\text { Reconciliation with counterparties is done on a quarterly } \\
\text { basis? }\end{array}$ & $\mathrm{X}$ & & 1 \\
\hline 12 & $\begin{array}{l}\text { Does the organization receive advance payment for the } \\
\text { upcoming shipment of finished goods is reflected as accounts } \\
\text { receivable? }\end{array}$ & $\mathrm{X}$ & & 1 \\
\hline 13 & $\begin{array}{l}\text { Is there a reconciliation of data in the registers of analytical } \\
\text { and synthetic accounting? }\end{array}$ & $\mathrm{X}$ & & 1 \\
\hline 14 & Is there any control over the correctness of documents? & $\mathrm{X}$ & & 1 \\
\hline 15 & $\begin{array}{l}\text { Is the correctness of primary documents of counterparties } \\
\text { always checked? }\end{array}$ & & $\mathrm{X}$ & 0 \\
\hline 16 & $\begin{array}{l}\text { Are computer programs used in accounting to determine the } \\
\text { financial result? }\end{array}$ & $\mathrm{X}$ & & 1 \\
\hline 17 & Do unannounced inspections and audits take place? & $\mathrm{X}$ & & 1 \\
\hline 18 & $\begin{array}{l}\text { Do the costs of circulation always have appropriate } \\
\text { documentary evidence? }\end{array}$ & & $\mathrm{X}$ & 0 \\
\hline
\end{tabular}




\begin{tabular}{|c|c|c|c|c|}
\hline 19 & Is grouping of expenses on ordinary activities ensured? & $\mathrm{X}$ & & 1 \\
\hline 20 & $\begin{array}{l}\text { Are measures taken to analyze the reasons for the deviation } \\
\text { of actual indicators from the planned ones? }\end{array}$ & $\mathrm{X}$ & & 1 \\
\hline 21 & $\begin{array}{l}\text { Is there a separate sub-account on account } 90 \text { for accounting } \\
\text { expenses for selling products? }\end{array}$ & $\mathrm{X}$ & & 1 \\
\hline 22 & $\begin{array}{l}\text { Are the expenses accumulated on account } 44 \text { written off in } \\
\text { full amount to the cost price of sold products (in the debit of } \\
\text { account 90)? }\end{array}$ & $\mathrm{X}$ & & 1 \\
\hline 23 & $\begin{array}{l}\text { Are the expenses on payment for labor and social needs } \\
\text { deductions recognized as expenses from the usual types of } \\
\text { activity? }\end{array}$ & $\mathrm{X}$ & & 1 \\
\hline 24 & $\begin{array}{l}\text { Is the amount of expenses associated with the disposal of } \\
\text { fixed assets recognized as other expenses? }\end{array}$ & & $\mathrm{X}$ & 1 \\
\hline 25 & $\begin{array}{l}\text { Does the organization use account } 45 \text { «Goods Shipped» } \\
\text { when selling goods under a commission contract? }\end{array}$ & $\mathrm{X}$ & & 1 \\
\hline 25 & $\begin{array}{l}\text { Does the organization have internal regulations for price } \\
\text { formation? }\end{array}$ & $\mathrm{X}$ & & 1 \\
\hline 26 & Is the list of ordinary activities of the organization limited? & $\mathrm{X}$ & & 1 \\
\hline 27 & $\begin{array}{l}\text { Is there a full-time controller position with a direct reporting } \\
\text { line to the manager? }\end{array}$ & & $\mathrm{X}$ & 0 \\
\hline 28 & $\begin{array}{l}\text { Does the organization have measures aimed } \\
\text { to strengthen internal control of financial results? }\end{array}$ & & $\mathrm{X}$ & 0 \\
\hline 29 & Does the organization estimate management costs? & $\mathrm{X}$ & & 1 \\
\hline
\end{tabular}

So, to evaluate the internal control system of financial results, the author developed 28 test questions given in Table 10, for a correct answer 1 point is given, and in case of an incorrect answer - 0 point, in the end all the points received for answers are summed up. On this basis, here are the evaluation criteria that characterize the internal control system of the «Karlinsky Meat House»:

- less than 12 - the level of the internal control system of financial results is low and requires significant changes;

- 13-17 - the level of the internal control system of financial results is average and requires checks for elimination of some errors;

- 19-29 - the level of internal control system of financial results is high.

Testing the system of internal control of financial results of «Meat House «Karlinsky» on the questionnaire from table 10 led to the conclusionthat the system of internal control of financial results has been established at a sufficiently high level ( 25 points), despite the absence of a full-time position of a controller; accounting is carried out in accordance with the regulatory legal acts of the Russian Federation in the field of accounting.

However, it is worth noting the following negative points identified during testing of internal control of financial results:

- lack of desire of management personnel to further strengthen internal control over financial results;

- insufficiently effective level of checks on the correctness of filling in primary documents of counterparties, since during the testing, the fact of falsification of the signature in the supplier's invoice was discovered, the data on which had already been entered in the accounting register last month;

- not all distribution costs are documented.

\section{Conclusions}

Thus, the results of the study allowed to form an organizational model of internal control of financial results, the main purpose of which is to minimize economic risks in the process of 
forming financial results; establishing the feasibility of business operations performed at the enterprise; ensuring the rational use of resources; identifying reserves to improve the efficiency of business processes; validation of the validity of management decisions.

Organization of internal control system on the basis of the proposed conceptual model will contribute to: ensuring the effective functioning and sustainable development of the enterprise in a competitive environment; preservation and effective use of resources of the enterprise; timely identification and minimization of commercial, financial and internal corporate risks in enterprise management; formation of information support system appropriate to modern conditions of management at all levels of management.

For improvement of methodical toolkit of internal control of financial results working documents of internal control are offered. The developed form of the program of internal control of financial results determines directions and intensity of control measures, contributes to their effective and timely realization.

On the basis of the working document «Checking the execution of primary documents» controllers check completeness and accuracy of execution of documents, filling of all necessary requisites; legality of operations and logical connection of separate indicators. With the use of a working document «Checking the timeliness of receipt of payment under the contracts» for each counterparty can promptly identify the formation of accounts receivable, to prevent the emergence of doubtful and overdue accounts receivable.

Recommendations on the development of methodological support of internal control of financial results will contribute to the organization of effective inspections in order to prevent the unjustified use of material, labor and monetary resources, the elimination of possible falsification of the data contained in the financial statements.

\section{References}

1. N. Dutta, D. Meierrieks, International Review of Economics \& Finance 73, 114-126 (2021) https://doi.org/10.1016/j.iref.2021.01.002

2. M. Delis, E. Galariotis, J. Monne, Journal of Banking \& Finance 123, 106035 (2021) https://doi.org/10.1016/j.jbankfin.2020.106035

3. K. Lo, F. Ramos, R. Rogo, Journal of Accounting and Economics 63, 1-25 (2017) https://doi.org/10.1016/j.jacceco.2016.09.002

4. J. Leontieva, E. Zaugarova, G. Klychova et al, MATEC Web of Conferences 170, 01087 (2018) doi.org/10.1051/matecconf/201817001087

5. A. Chen, J.J. Gong, Advances in Accounting 45, 100415 (2019) https://doi.org/10.1016/j.adiac.2019.03.003

6. Dz. Faizrakhmanov, A. Zakirova, G. Klychova et al, E3S Web of Conferences 91, 06004 (2019) https://doi.org/10.1051/e3sconf/20199106004

7. Th.D. Dowdell, D.N. Herda, M.A. Notbohm, Research in Accounting Regulation 26, 104-109 (2014) https://doi.org/10.1016/j.racreg.2014.02.011

8. M. Roussy, Critical Perspectives on Accounting 24, 550-571 (2013) https://doi.org/10.1016/j.cpa.2013.08.004

9. M. Hanskamp-Sebregts, P.B. Robben, H. Wollersheim, M. Zegers, Health Policy 124, 216-223 (2020) https://doi.org/10.1016/j.healthpol.2019.11.013

10. A. Zakirova, G. Klychova, R. Nurieva et al, Advances in Intelligent Systems and Computing 1259 AISC, 98-123 (2021) https://doi.org/10.1007/978-3-030-57453-6_10

11. Y. Li, X. Li, E. Xiang, H.G. Djajadikerta, Journal of Contemporary Accounting \& Economics 16, 100210 (2020) https://doi.org/10.1016/j.jcae.2020.100210 
12. G. Klychova, A. Zakirova, E. Sadrieva, et al, E3S Web of Conferences 91, 06002 (2019) doi.org/10.1051/e3sconf/20199106002

13. Kh. Kelly, H.-T. Tan, Accounting, Organizations and Society 56, 1-20 (2017) https://doi.org/10.1016/j.aos.2016.12.002

14. K. Chalmers, D. Hay, H. Khlif, Journal of Accounting Literature 42, 80-103 (2019) https://doi.org/10.1016/j.acclit.2018.03.002

15. J. Wang, K. Hooper, Critical Perspectives on Accounting 49, 18-30 (2017) https://doi.org/10.1016/j.cpa.2017.04.003

16. D.B. Bryan, Advances in Accounting 36, 11-26 (2017) https://doi.org/10.1016/j.adiac.2016.09.005

17. A. Klychova, G. Klychova, A. Zakirova et al, E3S Web of Conferences 110, 02072 (2019) doi.org/10.1051/e3sconf/201911002072

18. T.-Sh. Wang, Y.-M. Lin, H. Chang, International Review of Economics \& Finance 58, 312-329 (2018) https://doi.org/10.1016/j.iref.2018.04.003

19. G. Klychova, A. Zakirova, R. Mannapova, K. Pinina, Y. Ryazanova, E3S Web of Conferences 110, 02075 (2019) doi.org/10.1051/e3sconf/201911002075.

20. L. Khoja, M. Chipulu, R. Jayasekera, International Review of Financial Analysis 66, 101379 (2019) https://doi.org/10.1016/j.irfa.2019.101379

21. P.G. Thacker, R.J. Witte, R. Menaker, Clinical Imaging 64, 80-84 (2020) https://doi.org/10.1016/j.clinimag.2020.03.015

22. A. Zakirova, G. Klychova, G. Ostaev et al, E3S Web of Conferences 164, 10009 (2020) https://doi.org/10.1051/e3sconf /202016410009

23. H. Li, J. Dai, T. Gershberg, M.A. Vasarhely, International Journal of Accounting Information Systems 28, 59-76 (2018) https://doi.org/10.1016/j.accinf.2017.12.005

24. Y.-T. Chang, H. Chen, R.K. Cheng, W. Chi, Journal of Contemporary Accounting \& Economics 15, 1-19 (2019) https://doi.org/10.1016/j.jcae.2018.11.002

25. W. Shu, Y. Chen, B. Lin, Y. Chen, China Journal of Accounting Research 11, 407-427 (2018) https://doi.org/10.1016/j.cjar.2018.09.002

26. G.S. Klychova, A.R. Zakirova, E.R. Kamilova, International Business Management 10, 5254-5260 (2016)

27. Sh.-I. Chang, L.-M. Chang, J.-C. Liao, Information \& Management 57, 103335 (2020) https://doi.org/10.1016/j.im.2020.103335

28. E. Demirakos, The International Journal of Accounting 53, 253-254 (2018) https://doi.org/10.1016/j.intacc.2018.07.001

29. A. Briozzo, D. Albanese, Journal of International Accounting, Auditing and Taxation 38, 100302 (2020) https://doi.org/10.1016/j.intaccaudtax.2020.100302

30. S.F. Schantl, A. Wagenhofer, Journal of Accounting and Public Policy 1, 106803 (2020) https://doi.org/10.1016/j.jaccpubpol.2020.106803

31. X.-d. Ji, W. Lu, W. Qu, Journal of Contemporary Accounting \& Economics 14, 266287 (2018) https://doi.org/10.1016/j.jcae.2018.07.002

32. H. Shen, H. Xiong, Sh. Zheng, F. Hou, Economic Modelling (2020) https://doi.org/10.1016/j.econmod.2020.03.011

33. M. Eulerich, J. Kremin, D.A. Wood, Advances in Accounting 45, 100410 (2019) https://doi.org/10.1016/j.adiac.2019.01.001 